\title{
DIREITO E MORAL NAS PÓS-MODERNIDADE: ANÁLISE INTERDISCIPLINAR DO FILME “A PELE QUE HABITO”
}

\author{
LAW AND MORALITY IN THE POST-MODERN ERA:INTERDISCIPLINARY ANALYSIS OF THE
}

MOVIE "THE SKIN I LIVE IN"

\section{Mara Regina de Oliveira*}

\begin{abstract}
Resumo:
A proposta deste artigo é fazer um estudo pós-moderno da relação existente entre direito e moral. Nesta análise, supera-se a visão racionalista da moralidade moderna vista como um código moral único, como um conjunto de preceitos harmoniosamente coerentes ao qual todos nós deveríamos obedecer e que legitimaria as normas jurídicas de forma racional. Através de uma perspectiva interdisciplinar, como meio de expansão da reflexão crítica, analisaremos o filme A pele que habito dirigido por Pedro Almodóvar.

Palavras-chave: Direito. Moral. Pós-Modernidade. Cinema.
\end{abstract}

\begin{abstract}
:
The purpose of this paper is to make a postmodern study of the relationship between law and morality. This analysis overcomes the rationalist view of modern morality seen as a single moral code, as a set of harmoniously coherent principles to which we should all obey and which legitimizes the correct legal rationality. Through the interdisciplinary perspective, as a way to expand the critical thought, on analyze the film The skin I live in directed by Pedro Almodóvar.
\end{abstract}

Keywords: Law. Morality. Postmodern Era. Cinema.

O Direito se localiza dentro de um cenário complexo de obediência e revolta. O direito garante e oprime a liberdade, ao mesmo tempo. Compreender o direito não se resume a conceituações lógicas e racionalmente sistematizadas. Seu estudo exige não apenas inteligência, acuidade, mas também encantamento, intuição, espontaneidade. É preciso ter rigor técnico e abertura para o humano, ao mesmo tempo. ${ }^{1}$

\section{Introdução}

Este artigo pretende fazer uma aproximação interdisciplinar entre o estudo da relação existente entre direito e moral no cenário pós-moderno atual, a partir

\footnotetext{
* Mestre e Doutora em Filosofia do Direito, pela Pontifícia Universidade Católica de São Paulo, Professora Assistente Doutora na Faculdade de Direito da mesma universidade. Professora Doutora da Faculdade de Direito da Universidade de São Paulo.

1 FERRAZ JR, Tercio Sampaio. Introdução ao estudo do direito: técnica, decisão, dominação. 4. ed. São Paulo: Atlas, 2003. p. 21.
} 
das reflexões de Zygmunt Bauman, e do instigante filme de Pedro Almodóvar, A pele que habito (2011). Partimos do pressuposto epistemológico de que uma expansão da metodologia interdisciplinar, na esteira do pensador clássico Hilton Japiassu, se faz cada vez mais necessária no âmbito das ciências humanas e notadamente no estudo do direito. Ela resulta de uma combinação criativa e da integração orgânica de vários métodos de análise particulares podendo tornar-se instigante quando tem por base a associação de um estudo teórico jurídico com a análise de uma obra cinematográfica complexa, de qualidade artística relevante. Na epígrafe deste trabalho, o filósofo Tercio Sampaio Ferraz Jr. constata que o estudo crítico do direito só se mostra viável, na medida em que incorporar os elementos não racionais e ambíguos que compõem o fenômeno jurídico, que pode, ao mesmo tempo, ser visto como instrumento de controle e liberdade social. Nas palavras de Julio Cabrera, veremos como o cinema pode potencializar a nossa capacidade de reflexão zetética sobre temas jurídicos de relevância.

Segundo o pensamento de Edgar Morin, o cinema possibilita, de forma extraordinária, a ampliação de nossa consciência subjetiva, nos fazendo adentrar em esferas inacessíveis da nossa existência em termos concretos. Apesar do caráter ficcional do cinema, o efeito psicológico e estético da impressão da realidade, nos faz conhecer mais profundamente a realidade humana ao nosso redor, em termos lógicos e afetivos. Neste sentido, cabe lembrar da didática distinção feita por Hugo Munsterberg a respeito das emoções provocadas pelo cinema. Em primeiro lugar, teríamos as emoções que os personagens comunicam de dentro do filme, provocando simpatia pelo sofrimento ou mesmo compartilhando as alegrias pelo amor realizado A percepção visual das várias manifestações dessas emoções se funde em nossa mente com a consciência da emoção manifestada. É como se estivéssemos vendo e observando diretamente a própria emoção do personagem.

Reagimos, organicamente, de forma adequada, o horror nos dá arrepios, a felicidade nos acalma. Há uma experiência viva do reflexo emocional dentro da nossa mente. Nos filmes melodramáticos, este tipo emoção está muito presente. Mas, haveria, por assim dizer, um segundo tipo de emoção secundária em que a plateia reage às cenas do filme do ponto de vista da sua vida afetiva independente, onde pode haver, portanto, uma indignação moral e não uma identificação emotiva com o personagem. A nosso ver, estas duas formas de emotividade se combinam na experiência do filme, mas a emoção secundária estaria mais presente nos chamados filmes "cerebrais" e seria muito útil em atividades acadêmicas. $^{2}$

$\mathrm{Na}$ visão filosófica de Bauman, há confluência com o pensamento exposto por Ferraz Jr, na epígrafe do trabalho. Na sua abordagem pós-moderna da relação existente

2 MUNSTERBERG Hugo. As emoções. In: A Experiência do cinema: antologia/Ismail Xavier organizado. Rio de Janeiro: Edições Graal: Embrafilmes, 2008. p. 52-53. 
entre direito e moral, o autor busca justamente fazer uma leitura crítica dos modelos jurídico-filosóficos racionalistas, que integram a validade do direito e a moralidade, mostrando a sua insuficiência em termos de realidade humana concreta. Segundo o autor, a relação do direito com a moralidade dever ser vista como sendo ambivalente, não racional e a porética, toda ação moral se dá num campo de permanente incerteza e pode ter consequências imorais em relação ao outro. Nesta perspectiva, a pluralidade de juízos morais coloca em cheque a própria ideia moderna de ética vista como um código moral único, como um conjunto de preceitos harmoniosamente coerentes ao qual todos nós deveríamos obedecer e que legitimaria as obrigações jurídicas de forma racional. ${ }^{3}$ A análise do cinema em sintonia com a discussão teórica potencializa a percepção do aspecto afetivo e não racional que envolve o estudo do tema nos termos propostos por Bauman.

Em nossa análise, partimos do pressuposto de que o filme $A$ pele que habito apresenta um cenário pós-moderno da moralidade e sua relação com o direito, de forma problemática e aberta, não reduzível a modelos racionalistas teóricos universais. Aliás, esta mesma reflexão aparece em vários filmes do diretor, tais como Carne Trêmula, Tudo sobre minha mãe, Fale com ela, Má Educação, Volver e Abraços partidos. A escolha de seu último filme se deve pela excelência do rigor narrativo desenvolvido pelo diretor nesta obra. Não existe uma só cena supérflua na película, que não componha a narrativa de forma relevante. Seus personagens incorporam, de forma exemplar, comportamentos destoantes da ética moderna dominante, porém, eles, ao mesmo tempo, não podem ser simplesmente vistos como agentes praticantes de ações ilegais/imorais. Eles vivem numa zona pós-moderna e mais cinzenta da ética, onde as codificações binárias lógicas normativas desaparecem quando confrontadas com a realidade, a qual nos propomos a explorar neste artigo.

1. A importância da interdisciplinaridade no pensamento jurídico crítico

SegundoHilton Japiassu, emsua obraclássica intituladaInterdisciplinaridade e patologia do saber, as relações interdisciplinares figuram, em primeiro lugar, como uma exigência interna das ciências humanas, como uma forma de aprimoramento da realidade que elas visam conhecer. Mas também se impõem, como uma exigência externa, ou seja, como uma forma do homem responder às necessidades da ação, na forma de uma interpretação global da existência humana. Para o autor, conhecimento e ação devem se conjugar de forma dinâmica, ele critica o puro conhecimento enciclopédico, desvinculado da realidade que nos cerca. ${ }^{4}$ Segundo suas palavras:

$3 \quad$ BAUMAN, Zygmunt. Ética pós-moderna. São Paulo: Paulus, 1997. p. 29.

4 JAPIASSU, Hilton. Interdisciplinaridade e patologia do saber. Rio de Janeiro: Imago Editora, 1976. p. 29. 
Deve-se ultrapassar a dissociação entre o domínio do pensamento teórico e da ação informada. Sua exigência revela, não o real progresso, mas o sintoma de uma situação patológica em que se encontra o saber. O número de especializações exageradas e a rapidez de fragmentação de cada uma culminam numa fragmentação do homem do homem epistemológico. O saber foi esmigalhado, a inteligência se esfacelou, a razão perdeu a razão, desequilibrando a personalidade humana em seu conjunto. ${ }^{5}$

O interdisciplinar pode ser visto como uma espécie de "remédio" mais adequado a cancerização ou à "patologia" geral do saber. No entanto, o autor alerta que, caso se estas análises permanecerem superficiais, os remédios propostos também não atingirão o fundo das coisas, podendo até a torná-las mais graves. Neste sentido ele afirma:

Parece-nos que o grande desafio consiste tanto numa reorganização metódica dos estudos e das pesquisas, quanto da tomada de consciência sobre o sentido da presença do homem no mundo. É semelhante atitude que nos leva a conhecer o "fenômeno" interdisciplinar como uma maneira de encarar a repartição epistemológica do saber em disciplinas e das relações entre elas, pois se trata de uma das mais significativas mudanças que afetam, em nossa cultura, as démarches da inteligência e as formas de seu discurso. ${ }^{6}$

A interdisciplinaridade tem por característica essencial a incorporação dos resultados de várias disciplinas, tomando-lhe de empréstimo esquemas conceituais de análise com o intuito de integrá-los, depois de havê-los comparado e julgado. Envolve a troca generalizada de informações no meio científico, ampliando a sua formação geral, questionado a acomodação dos cientistas em seus pressupostos implícitos. Engaja o trabalho em equipe e a educação permanente, na forma de reciclagem continuada, no intento de preparar melhor os indivíduos para a formação profissional, que cada vez mais exige uma formação polivalente. ${ }^{7}$

Japiassu alerta que esta nova metodologia pode estar sujeita a modismos inconsistentes, e, neste sentido, poderia ser difícil apreendê-la com rigor, já que seu domínio é vasto e complexo. Levanta algumas questões instigantes. Ela surgiu na Europa, em meados dos anos sessenta, mas poderia ser importada por países em desenvolvimento? Ela seria um empreendimento realmente sério? Ela não poderia encorajar o diletantismo, os conhecimentos superficiais ou as ilusões de saber? ${ }^{8}$

$\mathrm{O}$ autor responde suas indagações traçando considerações críticas ao papel das universidades, que fragmentaram o saber em migalhas, pulverizado num número crescente de especializações, promovendo o divórcio esquizofrênico entre uma

\footnotetext{
Op. cit., p. 30.

JAPIASSU, Hilton. Interdisciplinaridade e patologia do saber. Rio de Janeiro: Imago Editora, 1976. p.31.

Op. cit., p. 32-33.

Op. cit., p. 42.
} 
universidade cada vez mais compartimentada e uma realidade dinâmica sempre percebida num todo concreto e indissociável. A universidade tem feito tudo o que pode para limitar e condicionar os indivíduos a funções estreitas e repetitivas, impedindo que suas potencialidades intelectuais desabrochem. ${ }^{9}$

Sem menosprezar as questões críticas levantadas por Japiassu, consideramos ser possível um estudo interdisciplinar sério e não identificado com modismos superficiais. As críticas do educador são extremamente atuais em relação ao que ocorre no ensino do direito em geral, onde, nos cursos de graduação, ainda prevalece o estudo dogmático jurídico, visto de forma distorcida e alijado de teorias jurídicas críticas próximas à realidade social. Sabemos que o estudo dogmático jurídico compõe-se de uma estratégia persuasiva e tecnológica de aceitação acrítica da validade das normas postas, visando a sua aplicação prática, na decisão de conflitos. Todavia, esta artificialidade não pode ser confundida com a efetiva exclusão da realidade e com o desprestígio das teorias que estudam o direito com o viés mais crítico e real. Ao contrário, sabemos que um competente raciocínio dogmático, com efetivo poder de persuasão, visando viabilizar a tomada de decisões, tem por base cognitiva a boa formação crítica das chamadas teorias zetéticas.

Só aquele que tem um raciocínio alargado sobre o direito consegue fazer os recortes estratégicos necessários, no campo da interpretação dogmática. Só aquele que conhece a linguagem jurídica, do ponto de vista crítico, consegue manipulá-la e conformá-la em prol da captação da adesão do seu interlocutor. No mundo complexo pós-moderno atual, vivenciamos problemas de legitimidade jurídico-política que, muitas vezes, colocam em cheque a própria imperatividade das leis estatais e sua relação com a moralidade institucional. Isto exige do estudioso e do futuro prático uma visão alargada e interdisciplinar dos estudos jurídicos. Embora a atual divisão curricular das faculdades de direito favoreça, teoricamente, o equilíbrio entre disciplinas de cunho zetético e dogmático jurídico, na prática do ensino, ainda se observa uma falta de integração efetiva entre elas. No seio deste estudo interdisciplinar, ganha destaque o estudo jurídico-crítico relacionado ao universo artístico. Em particular, faremos referência ao universo cinematográfico, relacionado ao tema da ética pós-moderna.

2. O papel epistemológico da arte como forma de conhecimento e reflexão crítica interdisciplinar

Segundo Edgard Morin, a maior contribuição, em termos epistemológicos, do século XX, foi o conhecimento dos limites do conhecimento. A maior certeza percebida é a indestrutibilidade das incertezas. Neste sentido, o autor destaca a necessidade de fazer a convergência de diversos ensinamentos, mobilizar diversas ciências e disciplinas

Op. cit., p. 43. 
para enfrentar as incertezas, revendo os axiomas da lógica clássica foram revistos, bem como a racionalidade científica tradicional. Percebemos pontos de convergência com o pensamento de Japiassu, mas o autor dá mais destaque ao papel da arte na composição interdisciplinar do conhecimento. ${ }^{10}$

As incertezas cognitivas estão referidas a três elementos básicos. Há um elemento cerebral, na medida em que percebemos que o conhecimento não apenas traduz, mas constrói o real, existindo sempre a chance de erro. Há um elemento físico, que de certa forma se liga ao primeiro, o conhecimento dos fatos depende, de forma permanente, da interpretação. Por fim, ele menciona a incerteza mais filosófica de todas, que diz respeito à crise dos fundamentos da certeza na Filosofia e nas ciências, conforme detalhamos no item anterior aos expormos o pensamento de Japiassu. ${ }^{11}$

A incerteza tem origem histórica e mostra o caráter caótico da condição humana, marcada por destruições irremediáveis. Segundo o autor, não há como submeter à história a um determinismo econômico-social ou levá-la a obedecer a um progresso. Estamos destinados à incerteza do futuro. As grandes guerras mundiais e as rupturas foram inesperadas. ${ }^{12}$ Morin propõe que haja um permanente e sincero diálogo com a incerteza e diz que pensar bem é estar consciente da ecologia da ação. Toda ação, uma vez iniciada, entra num jogo de interações e retroações no meio em que é efetuada, que podem desviá-la de seus fins e até levar a um resultado contrário ao esperado. As consequências da ação são imprevisíveis. ${ }^{13}$

Neste sentido, ele destaca que o papel da educação não seria apenas o de transmitir informações e conhecimentos sempre mais numerosos aos alunos, mas a transformação existencial do conhecimento adquirido em sapiência, que deve ser incorporado por toda a vida. Nesta linha de pensamento, ganha importância o contato com a cultura de humanidades, seja no campo da literatura, da poesia, do teatro ou mesmo do cinema. ${ }^{14}$ Nas palavras do autor:

Desde Shakespeare, sabe-se que uma única obra literária encerra um infinito cultural que engloba ciência, história, religião, ética. É no romance, no teatro, no filme que percebemos que o homo sapiens é, ao mesmo tempo, indissoluvelmente, homo demens, a existência revela a sua miséria e sua grandeza trágica, com o risco do fracasso, do erro e da loucura. ${ }^{15}$

10 MORIN, Edgar. A cabeça bem feita, repensar a reforma, repensar o pensamento. Rio de Janeiro: Bertrand Brasil, 2000. Cap. 4 Aprender a viver, p. 55-56.

11 Op. cit., p. 59.

12 Op. cit., p. 61.

13 Op. cit., p. 63.

14 Op. cit., p. 48.

15 MORIN, Edgar. A cabeça bem feita, repensar a reforma, repensar o pensamento. Rio de Janeiro: Bertrand Brasil, 2000 - Cap. 4 Aprender a viver,p. 49. 
A importância cognitiva do contato com a cultura de humanidades está numa ampliação de nossa vida subjetiva, que permanece até certo ponto inacessível em nossa vida concreta. No romance ou no espetáculo cinematográfico, a magia do livro ou do filme faz-nos compreender o que não compreendemos na vida comum, onde percebemos os outros de forma exterior, ao passo que na tela e nas páginas do livro eles surgem com todas as dimensões, subjetivas e objetivas. ${ }^{16}$

O papel da educação seria o de figurar como escolas de compreensão humana, capazes de potencializar o nosso humanismo. Podemos compreender que não podemos reduzir um ser a uma parcela de si mesmo, como geralmente se faz no quotidiano, onde somos quase indiferentes às misérias físicas e morais, sentimos a comiseração, a piedade e a bondade, ao ler um romance ou ver um filme. ${ }^{17}$

Segundo Morin, a compreensão humana nos alcança quando sentimos e concebemos os humanos como sujeitos que têm tristezas e alegrias. Quando reconhecemos no outro os mecanismos egocêntricos de auto- justificação, que estão em nós mesmos. É a partir dela que se pode lutar contra o ódio e a exclusão. Toda a percepção é uma tradução reconstrutora realizada pelo cérebro, a partir de terminais sensoriais, nenhum conhecimento pode dispensar interpretação. Cada um pode produzir a mentira para si mesmo, através de um egocentrismo justificador e a transformação do outro em bode expiatório de nossas frustrações. ${ }^{18}$

Em consonância com o pensamento de Japiassu, Morin destaca que, a partir do século XVIII, a racionalidade passa a ser vista como uma disposição mental que suscita um conhecimento objetivo do mundo exterior, elabora estratégias eficazes, realiza análises críticas e opõe um princípio de realidade ao princípio do desejo. Os avanços da ciência, da técnica e da economia confirmam a sua eficácia. No entanto, citando Platão e Freud, entende que especificidade racional é insuficiente porque ignora a loucura, a afetividade, o imaginário, o mitológico, o lúdico, o religioso. Menciona um interessante paradoxo: "Seria irracional, louco e delirante ocultar o componente irracional, louco e delirante do humano."19

O homem se apresenta como homo sapiens, faber e economicus. No entanto, destaca Morin, o homo faber também é killer, o homo sapiens exterminou os neandertalenses que viviam na Europa desde dezenas de milhares de anos antes da chegada do sapiens. A partir dos poderes da ciência e da técnica, que trouxeram avanços materiais, lançou-se à conquista mortal do planeta, extinguindo os índios e criando a escravidão. Nota-se que a agressividade tem estado presente na história humana, em

\footnotetext{
Op. cit., p. 50.

Op. cit., p. 51.

Op. cit., p. 53.

Op. cit., p. 117.
} 
conflitos religiosos e ideológicos. Existem, apenas o que ela chama de "algumas ilhas de bondade." 20

Segundo Morin, o homem tem uma natureza ambígua, ele é ao mesmo tempo, racional e irracional, como seres humanos, temos o que ele chama de dialógica homo sapiens-demens. Através de leis jurídicas e da inculcação, desde a infância, no espírito dos indivíduos, normas e interdições, a agressividade é inibida por regras de cortesia, também. Todavia, uma atitude agressiva ou uma humilhação despertam a nossa agressividade, o amor pode se transformar em ódio e romper controles. A linguagem imagética do cinema de arte tem o poder de penetração profunda em nossa consciência subjetiva, expondo, com maestria esta composição dialógica. Ela produz pensamento crítico, como veremos a seguir.

3. A arte cinematográfica como percepção profunda da nossa consciência subjetiva

O filósofo argentino, radicado no Brasil, Julio Cabrera, em consonância com o pensamento interdisciplinarde Morin e de Japiassu, defende a importante tese de que a filosofia, ao invés de ser considerada como algo concebido, historicamente, antes do cinema, poderia ser entendida como um saber mutável que se modifica através do diálogo com a chamada sétima arte, como elemento cultural relevante. Neste sentido, o pensar através da interpretação de imagens em movimento (ou em ilusão de movimento)assume um contorno não apenas voltado à racionalidade lógica, mas, também, a uma cognição da realidade que inclui um elemento afetivo (pático), primordial. ${ }^{21}$

Para a compreensão profunda de um problema filosófico, não basta entendêlo, racionalmente, como conceito teórico/semântico. Temos de vivê-lo, senti-lo, ser afetado por ele, como uma experiência emocional, não empírica, que aguce a nossa sensibilidade cognitiva, próxima de uma dimensão que poderíamos chamar de pragmático-impactante, a qual deve produzir algum tipo de transformação. Embora a forma literária tenha preponderado na história do pensamento filosófico, nada impediria que se viabilizasse uma problematização filosófica, através da análise de imagens do cinema, da fotografia, da ópera ou da dança. ${ }^{22}$

Mais adiante, ele levanta a polêmica hipótese de que o cinema seria uma linguagem mais apropriada do que a própria escrita, nesta forma de pensar dos filósofos, que ele chama de logopáticos. Algumas questões humanas não podem apenas ser ditas e articuladas logicamente. Elas devem ser apresentadas, sensivelmente, por meio de uma compreensão logopática, racional e afetiva, que, longe de ser uma mera impressão

\footnotetext{
20 Op. cit., p. 117.

21 CABRERA, Julio. O cinema pensa: uma introdução à filosofia através dos filmes. Rio de Janeiro: Rocco, 2006. p. 15-16.

22 Op. cit., p. 17.
} 
psicológica, tem pretensão de verdade universal. Como forma de pensamento, ele é tão aberto como a filosofia dita literária, não existe uma definição que o alcance em termos absolutos. Percebemos a pertinência da linguagem imagética do cinema para captar, em termos profundos, a dialógica homo sapiens-demens. ${ }^{23}$

Cabe aqui mencionar o pensamento de Jean Epstein sobre a questão. Como Cabrera, ele destaca a grande proximidade simbólica da imagem com a realidade sensível, que ela representa, em comparação com a palavra. Esta apresentaria uma espécie de símbolo indireto, elaborado pela razão, relacionado ao poder de abstrair, classificar e deduzir. A percepção da imagem em movimento constitui uma significação semipronta, que alcança, de forma contundente e indutiva, a emotividade do espectador, sem a mediação do raciocínio abstrato. Já a palavra, para produzir uma emoção, depende de uma prévia decodificação racional de seu significado, para que represente uma realidade e esteja apta a mexer com sentimentos.

Para que a linguagem cinematográfica seja vista, do ponto de vista filosófico, é necessário que percebamos que ela se constrói a partir dos chamados "conceitosimagem", que não se confundem com os tradicionais "conceitos-ideia", trabalhados na filosofia escrita. No pensamento de Cabrera, eles não têm um caráter essencialista e definitivo, mas, sim, heurístico e crítico. Eles caracterizam uma experiência que se tem para que possamos entender e trabalhar este conceito, na forma de um "fazer coisa com imagens".

Não se trata, apenas, de assistir ao filme como uma experiência estética ou social desarticulada do raciocínio ou ler um comentário sobre a película, mas de desenvolver uma interação lógico-afetiva, que evidencie a presença de conceitos ou ideias nas imagens em movimento. Já entendemos como a linguagem do cinema é poderosa porque produz a famosa "impressão da realidade", acompanhada pela identificação com o olhar dos personagens, numa situação dinâmica de espacialidade e temporalidade construídas.

Os conceitos-imagem do cinema produzem um impacto emocional sobre questões que dizem respeito ao humano, com valor cognitivo, persuasivo, unindo lógica e prática, concomitantemente. Este impacto emocional não está ligado a um possível efeito dramático de um filme, do tipo melodrama, muitos filmes considerados "cerebrais" comovem o espectador pela sua "frieza". Por mais racional que seja um filme, ele nunca será abstrato como um tratado literário filosófico.

A produção do impacto emocional é fundamental para a eficácia cognitiva do conceito-imagem, a técnica cinematográfica se vale da pluriperspectiva, da manipulação do tempo e espaço e do corte cinematográfico para viabilizar este efeito estético. A

23 Op. cit., p. 18. 
pluriperspectiva se constitui graças a sua capacidade de dar "saltos" da primeira (o que vê ou sente o personagem), que é subjetiva, para a terceira, que é objetiva (o que vê a câmera). Neste sentido, a montagem, dentro dos planos, o ângulo aberto ou fechado da câmera e seu movimento podem tornar intensa a experiência do cinema. Isto se associa à enorme capacidade de manipular tempo e espaço, avançar e retroceder, inverter ou mesclar a ordem cronológica do passado e do futuro, mostrar espaços simultâneos, e articular o literal e o metafórico, como só os sonhos podem. Por fim, temos a maneira aberta e plural de conectar os planos, as cenas e as sequências. ${ }^{24}$

A técnica cinematográfica possibilita a instauração da experiência logopática, que permite a manifestação dos conceitos-imagem, que só podem ser gerados por ela e não por meios literários ou fotográficos. Outra característica importante seria a de que eles sempre apresentam desfechos abertos a novas problematizações filosóficas, mesmo que a intenção do diretor seja a de fechá-las, a linguagem da imagem tem uma natureza subversiva em termos de estrutura. Neste sentido, as soluções lógicas da filosofia escrita geralmente têm uma intenção de apresentar conclusões mais conciliadoras, conservadoras e construtivas, simbolicamente, bem educadas, como uma tentativa de "resolver o mundo dentro da cabeça", que o cinema não consegue fazer, mesmo que tente. ${ }^{25}$

Partindo desta reflexão de Cabrera, voltada para a filosofia geral, entendemos que, no campo da teoria do direito, existem instigantes linhas filosóficas literárias páticas, que permitem uma aproximação muito rica com a linguagem imagética na apreensão de temas, que envolvem uma delicadeza sutil da compreensão do humano, em uma dimensão mais profunda. Toda a instigante discussão teórico-filosófica sobre a relação entre direito e moral no plano real dos fatos e das condutas efetivas, envolve esta aproximação experiencial emotiva que vai muito além da racional compreensão semântico-lógica de enunciados escritos nos textos legais dogmático ou teorias filosóficas racionalistas. Tratase de um ramo do direito onde o humano envolve-se, diretamente, nas questões teóricas primordiais, principalmente quando indagamos a respeito da sua imperatividade concreta. É o que analisaremos a seguir, através do pensamento pático e inovador do pensador Zygmunt Bauman.

4. Direito e moral na pós-modernidade: a percepção cognitiva das incertezas e ambivalências

Segundo o pensamento de Zygmunt Bauman, existe a possibilidade de se compreender fenômenos morais de uma forma nova, com o advento da pós-modernidade, que não teria propriamente um sentido cronológico, mas cognitivo, relacionado a percepção

\footnotetext{
$24 \quad$ Op. cit., p. $31-32$.
}

25 Op. cit., p. 34. 
da insuficiência dos modelos teórico-racionais modernos. Ele propicia a retirada do que ele chama de "máscara das ilusões", de certos de certos objetivos éticos inatingíveis, criados pela modernidade a partir de modelos não realistas racionais. A pós-modernidade significaria a tomada de consciência das incertezas cognitivas destacadas por Japiassu e Morin. Neste sentido, há um rico diálogo comum epistemológico entre estes três autores.

Contemporaneamente, existem novos problemas morais, desconhecidos por gerações passadas ou não percebidos por elas. A agenda moral de nosso tempo está permeada de itens em que os escritores éticos do passado mal ou sequer tocaram, pois em, sua época, não eram articulados como parte da experiência humana. Temos, por exemplo, as situações de relacionamento entre casais, de parceria sexual e familiar notórias por sua subdeterminarão institucional, flexibilidade, mutabilidade e fragilidade. ${ }^{26}$

A abordagem pós-moderna da ética não abandona os conceitos morais próprios da modernidade, mas refuta as formas tipicamente modernas de tratar os seus problemas morais, ou seja, através de regulações normativas coercivas na prática política e na busca filosófica de absolutos universais. Na visão do autor, os grandes temas da ética não perderam a sua atualidade, mas necessitam de um olhar crítico novo, que estude o tema a partir da análise do real e não de modelos racionais universais. ${ }^{27}$

O Autor destaca que, na tradição, a vida em seu conjunto era uma criação de Deus, monitorada pela providencia divina. A vontade livre era a liberdade de escolher o errado contra o certo, isto é, de transgredir os mandamentos de Deus, tudo que se afastava do costume era uma transgressão deste tipo. Constrói-se um modelo estático de regulação jurídica, onde partiríamos de conteúdos jurídicos universais, baseados numa moralidade teológica jusnaturalista. ${ }^{28}$

Comoafrouxamento datradição, aracionalidadeemergenteno Renascimento, fez com que, com a crescente pluralidade de contextos mutuamente autônomos, homens de mulheres fossem lançados na condição de indivíduos dotados de identidades, ainda não previamente dadas, em termos espirituais, que deviam ser construídas, através de escolhas, que precisam calcular, medir e avaliar. Os desenvolvimentos modernos racionalistas forçaram os homens e as mulheres a tornar-se de indivíduos livres com suas vidas fragmentadas, separadas em muitas metas, sem que uma ideia onicompreensiva do mundo e unitária do mundo norteasse suas ações. As pessoas não adquiriram uma mentalidade individualista à medida que ficaram sem Deus. Ao contrário, a secularização seria resultado do individualismo. ${ }^{29}$

\footnotetext{
BAUMAN, Zygmunt. Ética pós-moderna. São Paulo: Paulus, 1997. p. 5.

Op. cit., p. 5.

Op. cit., p. 9.

BAUMAN, Zygmunt. Ética pós-moderna. São Paulo: Paulus, 1997. p. 10.
} 
Neste contexto de expansão da racionalidade secular, houve a permanente busca de um arranjo racional da convivência humana - um conjunto de leis ético-jurídicas concebida como algo que viabilizasse aos indivíduos, exercendo a sua vontade livre, a escolha do que seria reto e apropriado e não o que é errado e mau. A liberdade deveria ser monitorada, pois poderia tornar-se inimiga do bem, na medida em que ela seria imprevisível. ${ }^{30}$

Os filósofos e os legisladores se articulam em profícua cooperação e passam a exercer o papel de controladores sociais, reprimindo o caos e mantendo a ordem, colocando em xeque os impulsos indóceis e potencialmente ruins do homem. Percebemos uma intenção clara de soterrar a presença psicológica do homo demens e dar destaque social ao homo sapiens, que deveria prevalecer. Do ponto de vista interno, estes instintos deveriam ser reprimidos com a expansão da racionalidade, e, do ponto de vista externo, expondo os indivíduos a punições jurídicas externas. Havia a expectativa de que, por serem seres racionais, eles reagiriam a manipulações de recompensas e punições éticojurídicas, no seu julgamento individual, moldando o seu comportamento. ${ }^{31}$

De um ponto de vista teórico e ideal, deveria haver uma confluência entre o interesse individual e a obediência à ordem posta pelos legisladores. Porém, ao mesmo tempo, nota-se que sempre houve resistência dos indivíduos, com autonomia de julgamento, a interferência da heterônoma e externa legislação. $\mathrm{Na}$ prática, não se eliminou a presença subversiva do homo demens, sempre ocorreu a tendência anárquica individual de rebelião contra regras ético-jurídicas, sentidas como opressão. Do ponto de vista institucional, há a permanente tentativa de reforço do status quo, em nome do bem comum. Nas palavras de Bauman:

A modernidade tenta, a todo custo, resolver esta aporia, crendo numa solução racional. O moderno pensamento ético, em cooperação com a moderna prática legislativa, vale-se das bandeiras gêmeas da universalidade e da fundamentação. $\mathrm{Na}$ prática dos legisladores, a universalidade significou o domínio de um conjunto de leis no território sobre o qual estendia a sua soberania. Já os filósofos, viam as prescrições éticas universais que compelia a toda criatura humana reconhecê-lo como direito e a aceitá-lo como obrigatório. ${ }^{32}$

As duas universalidades, a jurídica e a filosófica, não se fundem, mas deveriam estabelecer uma relação de cooperação. Os filósofos naturalizaram, transformando em racional, algo criado convencionalmente pelos homens, o artifício cultural ou administrativo dos legisladores. Em contrapartida, os poderes legislativos

\footnotetext{
30 Op. cit., p. 11

31 Op. cit., p. 13

32 Op. cit., p. 14.
} 
coercitivos do Estado eram vistos, pela crença popular, como bem fundamentados, seguilos era coisa certa a fazer. Isto facilitaria o controle punitivo do Estado, na medida em que esta poderia parecer legítimo. O pensamento e prática morais da modernidade defendiam a crença na possibilidade de um código ético não ambivalente e não aporético. ${ }^{33}$

A pós-modernidade vê a impossibilidade deste código ético universal e fundamentado de forma inabalada, calcado numa moralidade não aporética e não ambivalente. A própria modernidade é que vem demonstrando a sua própria impossibilidade, a vaidade de suas pretensões e o desperdício de seus trabalhos. Seus ideais teóricos resultaram numa flagrante impossibilidade prática.

Os seres humanos não são essencialmente bons ou essencialmente maus. Segundo Bauman, na esteira do que foi abordado por Morin, de fato, os seres humanos são moralmente ambivalentes. As instituições político-jurídicas desenvolvem esta ambivalência como material de construção, tentando, de forma fracassada, purificá-la deste "pecado moral" ou como "ilicitude jurídica". Este impulso ambivalente não pode ser anulado, apenas reprimido. Muitas vezes, esta repressãoresultou em mais crueldade e menos humanidade. ${ }^{34}$

As ações morais não são regulares ou previsíveis de forma que lhes permitissem ser guiadas por regras. Elas são não racionais, não podem ser exauridos por qualquer código ético, segundo padrões normativos. Nestes, seria possível prover regras nítidas para a escolha de ações adequadas e inadequadas. Em cada situação de vida, seria possível fazer uma escolha boa, como deve ser, em detrimento de outras. A tradição moderna fracassa ao negar a existência de uma real zona cinzenta, no campo do certo/ errado. $^{35}$

Poucas escolhas morais são boas sem ambiguidade, a maior parte delas é feita por impulsos contraditórios. Quase todo impulso moral pode levar a consequências imorais. $\mathrm{O}$ eu moral move-se, sente-se e age em contexto de ambivalência e é acometido pela incerteza. A existência de uma situação moral isenta de ambiguidade é utópica. Raramente, atos morais podem trazer completa satisfação. ${ }^{36}$

O cinema de Pedro Almodóvar espelha ricos conceitos imagens que podem ser conectados a esta problemática moral pós-moderna exposta por Bauman. Em vários filmes, há uma rica exposição logo páticada ambivalência, irracionalidade e aporia moral, presente nas relações humanas. Ainda que vários de seus personagens transgridam regras morais dominantes e confrontem a legalidade objetiva, a questão do certo e do errado permanece em aberto para reflexão. Seus complexos personagens são profundamente

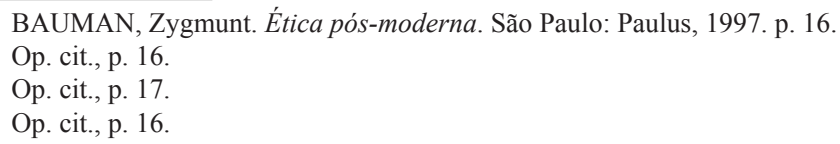


ambíguos e estão além da mera caracterização de praticantes de ilicitude e seres imorais. Trata-se de um diretor autoral, que expõe, através de uma linguagem imagética rigorosa e crítica, toda a zona cinzenta que permeia a ligação entre legalidade/ilegalidade, entre moralidade/imoralidade. Em vários filmes, temas como pedofilia, estupro e assassinato são abordados nesta perspectiva pós-moderna. Escolhemos analisar o sóbrio filme $A$ pele que habito, que trata do tema filosófico-jurídico com perfeição narrativa ainda maior do que a exposta em filmes anteriores. Ele contrapõe, de modo instigante, um conflito moral ambivalente entre a ideia de justiça como vingança, que leva ao desejo de dominação de outrem, que, em contrapartida, gera neste sentimento de injustiça pela opressão sofrida e desejo de libertação da dominação sofrida. É o que veremos a seguir.

4. A pele que habito: a exposição logopática das aporias morais pós-modernas

O filme A pele que habito (La piel que habito) é considerado por muitos como sendo o melhor filme de Pedro Almodóvar. Trata-se de um filme mais sóbrio e mais discreto que os anteriores, dotado de rigor técnico primoroso com o uso da câmera e na escolha das cores de composição dos cenários. A interpretação dos atores é primorosa e precisa, na sua complexidade. Usa a pluriperspectiva de diversos personagens, numa cronologia narrativa não linear, mas bastante consistente, como um todo. A película inicia pelo meio, no ano de 2012, retroage seis anos (2006), para contar o início da narrativa, para depois voltar a conclusão da estória, em 2012. Ao final, vemos que o quebra-cabeça narrativo se encaixa com perfeição vai nos surpreendendo ao longo de sua exposição. A cada nova descoberta sobre a complexa história dos personagens, fazemos uma reavaliação ética, em termos logopáticos, sobre o comportamento deles. A trilha sonora de Alberto Iglesias, velho parceiro artístico do diretor, favorece a expansão desta tensão ética, que vai sendo construída entre os personagens ao longo da trama.

Em termos pós-modernos, mostra como um impulso moral radical pode levar a consequências imorais em relação ao outro que é afetado por ele. Seus personagens apresentam faces racionais e irracionais e uma rica ambivalência moral, que muitas vezes confronta o sentido da legalidade e da moralidade dominante. $\mathrm{O}$ roteiro é original, escrito em coautoria com seu irmão Agustín Almodóvar, mas baseia-se, de forma assumida, no livro Tarântula/Mygale (Thierry Jonquet) e também no clássico francês Olhos sem rosto/ Les yeaux sans visage (Georges Franju, 1959). Embora possamos perceber a influência deste filme francês na composição da figura do medico cirurgião plástico Robert Ledgard (Antônio Banderas) e suas experiências ilegais moralmente motivadas por um sentido peculiar de justiça (com menção expressa ao tema do transplante de rosto, presente nos dois filmes), consideramos o trabalho de Almodóvar mais complexo e superior em termos filosófico-jurídicos e logopáticos. 
O filme inicia em 2012, mostrando uma câmera panorâmica na histórica e tradicional cidade de Toledo e de uma rica propriedade particular nos arredores, mas afastada do centro. A seguir, o olhar da câmara, em close-up, nos faz adentrar ao El Cigarral, de fora para dentro, observamos pela a janela, com grades, uma silhueta humana, depois a câmera de vigilância. Ao longo do desenvolvimento da película, vamos entender melhor a importância narrativa destas cenas de abertura que contrapõem, em termos de conceito-imagem, os valores opostos da tradição histórica da cidade de Toledo e do universo particular pós-moderno da clínica medica.

A câmera nos leva, a seguir, ao quarto de uma misteriosa jovem mulher (Elena Anaya), vestida com um elegante collant bege, que parece se confundir com a sua própria pele, fazendo poses de ioga, cortando tecidos e os colocando em esculturas de Louise Bourgeois, rasgando seus vestidos no guarda roupa. Aos poucos, percebemos que ela é prisioneira deste quarto, recebe alimentação através de um elevador e livros (Alice Munro - Escapada) para se ocupar. No primeiro encontro com o médico Robert, percebemos a revolta da mulher, ela faz um corte em seus seios a fim de deformar a própria pele. Almodóvar nos instiga a ir montando o significado narrativo destas cenas de revolta da personagem feminina Vera.

Quando o médico chega em casa, à noite, observamos o predomínio do azul cirúrgico, em sua maleta, na sua camisa e nos cenários em geral. Vemos que, nesta ampla casa, com marcante arquitetura tradicional, na região histórica de Toledo, há um sofisticado laboratório de pesquisas científico-médicas e um centro cirúrgico, privado, que se desenvolve na informalidade normativa. Sua figura séria e concentrada espelha a precisão do homo sapiens/faber, ou seja, da precisão técnica do pesquisador competente. O sentido destas cenas estranhas fica em aberto no início, mas instigam a nossa curiosidade. Aos poucos, Almodóvar nos convida a montar o quebra-cabeça narrativo, que tem um sentido rigoroso. Somos informados, aos poucos, de que Robert teria uma vida dupla em termos morais e jurídicos. El Cigarral funciona como uma clínica informal de experimentos transgênicos em seres humanos e cirurgias ilegais. Ele construiu uma pele transgênica, feita com sangue de porco, através de métodos científicos antijurídicos.

Aos poucos, também percebemos que Vera não é apenas prisioneira, mas cobaia humana de Robert. Ele implantou nela, de forma coativa, a pele transgênica Gal, resistente à picada de inseto, inclusive. No início, Robert não consegue ter poder ou domínio sobre Vera, ou seja, controlar a sua seletividade, ele tem de usar de meios coativos para impedir que o seu constante e irrebatível desejo de fuga daquela prisão torne-se realidade. Oferece ópio para acalmá-la e torná-la dócil, ela é permanentemente vigiada por câmeras. Aqui vemos uma sutil menção à sociedade disciplinar e panóptica em que vivemos, tão bem exposta por Michel Foucault. O sujeito deve sentir-se vigiado e se acomodar "espontaneamente" ao status quo, os efeitos da vigilância devem ser 
permanentes, ainda que esta seja descontínua, em termos de realidade. Mas nem mesmos estas câmeras tinham a capacidade de conformar o comportamento rebelde de Vera.

Formalmente, no espaço público, Robert aparece proferindo aulas e palestras, exibindo uma racional autoridade médica, o seu aspecto homo sapiens/faberé que predomina, neste ambiente. Ele afirma em uma de suas palestras, que parece ser dirigida para universitários, assumindo o seu lado homo sapiens/faber:

$\mathrm{O}$ rosto nos identifica. Para as vítimas de um incêndio não basta que salvemos suas vidas. Necessitam de um rosto, nem que seja de um morto. Um rosto com traços para que possam gesticular. Eu participei de três de nove transplantes de rosto que foram realizados no mundo, posso lhes assegurar que foram as experiências mais emocionantes da minha vida. Para uma massa disforme adquirir as características que lhe deem expressão, temos de moldar os músculos, articulando a musculatura facial, com suas correspondentes terminações nervosas.

Numa segunda palestra, que parece ter como público seus colegas médicos, ele faz a apresentação da pele Gal, que é relatada como sendo o resultado de experimentos testados em animais. De forma magistral, o início de sua fala oficial é sobreposta às imagens do ato não oficial de testar a resistência da pele de Vera contra picadas de mosquito, o homo demens e sapiens se fundem nesta cena:

Esta pele é resistente a picadas de qualquer inseto, o que se supõe seja uma barreira natural à malária, por exemplo. Naturalmente, fiz um rigoroso controle de qualidade dos tecidos implantados em mamíferos, em ratos atímicos e os resultados foram espetaculares. O que nos faz supor que seria igualmente positiva em seres humanos.

Estas cenas têm valor narrativo, pois nos possibilitam ver como Robert transita em dois mundos distintos, o da modernidade pública e o da pós-modernidade privada e secreta. No espaço público oficial, ele esconde a sua cobaia humana e simula a confirmação da legalidade posta e moral dominante em torno da proibição do uso da transgênese em tecidos humanos. Quando um colega espectador de sua palestra, que parece ser presidente de um comitê de ética médica, percebe que há algo de peculiar em sua apresentação, ele acaba assumindo que faz transgênese, utilizando células de porco. Embora ele esboce um tipo de questionamento sobre a legitimidade da proibição afirmando "por que não podemos aproveitar os avanços da ciência para melhorar a nossa espécie, já que intervimos em tudo", ele afirma ao presidente, e, posteriormente, a outro colega, que irá cessar seus experimentos, que nas suas palavras dissimuladas apenas representam "uma aventura pessoal, feita em memória de sua esposa, para ampliar os conhecimentos dele." Sabemos que esta é uma grande inverdade dita por ele, sua cobaia humana desperta nele interesses científicos e pessoais. A postura de Robert representa a radicalização do 
conceito contemporâneo de técnica, que se aparta da noção filosófica de virtude, própria do mundo antigo, propondo-se a manipular ou mesmo reconstruir a natureza das coisa. ${ }^{37}$

No decorrer da película, aos poucos, percebemos um aumento de complexidade na personalidade de Robert, que deixa o simples papel de dominador de Vera, na medida em que ele começa a sentir-se atraído, em termos sexuais e afetivos, por ela. Ele a observa, de seu quarto, através de uma grande tela LCD, Almodóvar faz uma rica menção ao poder de impacto emocional do close-up da câmera de vídeo que fixa em detalhes o roto de Vera. Quando Robert demonstra empatia por ela, comunicando uma relação de simetria, ao fumar ele próprio o ópio em sua companhia, Vera muda de atitude, de forma clara a nós espectadores do filme. Ela tenta conquistar a confiança do médico (que parece ficar confuso) e mesmo se propõe a seduzi-lo para a convivência amorosa. Ela é um experimento finalizado e afirma: "Sou tua, fui feita sob medida para você." Marília (Marisa Paredes), fiel governanta da casa, aconselha Robert a matar a sua cobaia, mas ele pede para ela despedir os empregados e não contratar mais ninguém. Robert se deixa seduzir por sua obra.

A visita Zeca (Roberto Álamo), filho de Marília, ao El Cigarral, depois de cometer um assalto a uma joalheria, provoca uma reviravolta na história. Ele reconhece Vera, através dos monitores, e fica fortemente atraído por ela. Sua ridícula fantasia de tigre, além de um disfarce para esconder da polícia, parece ser uma metáfora do seu instinto predador. Usa da força física para conter Marília, invade o quarto e se relaciona sexualmente com ela. Vera não o reconhece, mas pede a ele que a tire de lá, se posicionando coma aliada dele. Percebemos o desconforto físico de Vera durante o ato sexual, ela sente dor durante a penetração peniana de Zeca. Robert chega e dá dois tiros mortais em Zeca, depois de mirar a arma para Vera também. Observamos mais um confronto de Robert aos padrões morais e jurídicos dominantes. Ele agora praticou o ato ilícito do assassinato e, ao poupar Vera, condenará, sem saber, a si mesmo à morte, como veremos adiante.

Robert sai para enterrar informalmente o corpo de Zeca, Marília, extremamente emocionada e abalada, abre a sua intimidade para Vera, de forma inusitada. Zeca e Robert são irmãos, por parte de mãe, sem saber, cresceram juntos em conflito. Zeca e é filho de um antigo empregado da casa e Robert do rico patrão de Marília, que o adotou como filho. Na fase adulta, Zeca tornou-se um criminoso e amante de Gal, mas, no ato de fuga, ela teve o seu corpo queimado por inteiro, após um acidente de automóvel fatídico. Robert a salvou, com muita dedicação de médico e marido, mas ela se mata, na frente da filha, jogando-se da janela, ao ver a sua imagem deformada refletida no vidro, quando tenta observar a filha cantar a música que ela ensinara, versão em espanhol da

37 FERRAZ JR, Tercio Sampaio. Introdução ao estudo do direito: técnica, decisão, dominação. 4. ed. São Paulo: Atlas, 2003. p. 325. 
sensível música brasileira Pelo amor de amar, em clara manifestação de carinho pela mãe. Conseguimos compreender, neste momento, que a morte de Zeca significa, algo maior para Robert, a confirmação de um sentido vertical de justiça, associado à vingança pelo ato de traição praticado no passado. Almodóvar nos mostra que uma conduta tida como imoral e antijurídica, em termos dominantes, pode ter um sentido moral ambivalente e particular para um indivíduo. Marilia, diz que os dois filhos "são loucos", e que sempre soube que um dia iam se matar.

Após o retorno de Robert, que enterrou, informalmente, o corpo de Zeca nos arredores, ambos iniciam um relacionamento amoroso intenso, mas Vera queixa-se de dores na vagina que impedem a realização plena do ato sexual. Robert está dominado por Vera integralmente, tudo se encaminha para uma trágica inversão de papéis. O homo demens de Robert está apaixonado por Vera. Os dois dormem, e cada um sonha com uma versão diferente do início da polêmica estória entre ambos, numa rica pluriperspectiva cinematográfica. Neste ponto, a riqueza da narrativa do filme alcança o seu ápice, na medida em que Almodóvar mostra, como, na realidade, nossa consciência subjetiva tem um acesso restrito à própria realidade que nos cerca. Vera e Robert conhecem diferentes versões da realidade trágica em que viveram, que nunca irão se integrar, por isso a ambivalência moral persistirá até o fim. O filme volta ao começo, através da exposição memória onírica do Robert, em primeiro lugar.

Nesta versão, sua filha, Norma, ainda em sério tratamento psiquiátrico, depois de presenciar o suicídio violento da mãe, quando criança, é liberada pelo médico e vai com Robert a uma festa de casamento. Lá ela conhece um rapaz chamado Vicente (Jan Cornet), que também toma muitos medicamentos psiquiátricos. Ficamos sabendo que ele costura vestidos femininos, numa oficina de moda gerida pela mãe e por uma empregada. Robert sai da casa, observa vários casais em intimidade física no jardim, e encontra a sua filha desmaiada no jardim, após o início de uma relação sexual forçada. Vê Vicente indo embora com a moto e acredita que ele tentou violentar, sexualmente, a sua filha. Ele a acorda e a reação dela é muito agressiva com ele. $\mathrm{O}$ estado psicológico de Norma se agrava, ela é internada e passa a repelir o pai, de forma radical, como se este fosse de fato o seu agressor sexual. Em desespero, comete o suicídio, de forma semelhante ao cometido pela mãe, jogando-se de uma janela.

Neste momento chegamos a um ponto chave da compreensão da trama e que nos explica o porquê do extravagante aprisionamento de Vera feito pelo médico. O encarceramento não foi feito em virtude de um ato de violência banal por parte de Robert, que não é retratado por Almodóvar como um ser perverso em termos absolutos. Houve, segundo o ponto de vista particular dele, a transgressão de padrões éticos e jurídicos dominantes, justificada pela afirmação de outro sentido de justiça maior, já que trata de um personagem que está acostumado a desvios éticos e jurídicos. Tomamos ciência de que 
ele já realizava, nesta época, cirurgias de mudança de sexo ilegais na sua clínica, bastante prestigiada pelos pacientes e com o apoio de vários colegas médicos. Robert parece descrer que se possa fazer justiça ou pesquisas médicas consistentes e inovadoras, através da confirmação da legalidade oficial da modernidade. No fundo, seu ato transgressor significa o questionamento da legitimidade moral da legalidade imposta pelo Estado e a necessidade da ciência superá-la, se quiser avançar com eficiência.

Com a morte trágica da filha, Robert arma um maligno e abusivo plano de vingança, expondo, em termos logopáticos, o que no campo da Filosofia do Direito se costuma chamar de sentido vertical e emotivo de justiça, identificado com ideia de vingança (timoria). Sequestra Vicente, de forma violenta, simulando a morte deste num acidente. Muda o seu sexo, contra a sua vontade, com o apoio de sua equipe médica informal. Também muda toda a sua pele e seu rosto, através de várias cirurgias plásticas, até transformá-lo em Vera, uma réplica quase perfeita de sua falecida esposa Gal, numa clara tentativa de fazê-la voltar à vida. Numa belíssima cena, onde a técnica de sobreposição de imagens domina, Almodóvar nos revela que Vera e Vicente são as mesma pessoa. ${ }^{38}$

O ódio e o desejo violento e irracional de vingança, de impingir um mal àquele que matou a sua filha, expõe o homo demens do médico, de forma contundente. Mas graças à competência técnica e médica racional do homo sapiens/faber toda a transformação de sexo se opera de forma perfeita em termos técnicos, o resultado é a construção de uma obra de arte. Vera assume um papel ambíguo na vida de Robert, ela simboliza a confirmação sangrenta de sua justiça vertical e a afirmação do seu talento final e superior como cirurgião plástico. Todavia, esta transformação física de sexo foi suficiente para que houvesse uma transformação de sua identidade interior? Vera se sente, de fato, uma mulher? A identidade de gênero masculina de Vicente deixou desapareceu junto com o seu corpo?

Para que entendamos melhor a indignação moral de Vera e sua revolta, Almodóvar nos apresenta conceitos imagem que expõem a consciência subjetiva dela, que não pode ser conhecida por Robert. O fato é que, desde o início, Vicente nega, quando encarcerado, que tenha feito algo ruim para Norma, em termos intencionais, tudo não passou de uma triste fatalidade. Na sua versão dos fatos, não houve tentativa de violação forçada de Norma. Eles se conheceram na festa e, juntos, com outros jovens, foram namorar, no jardim, com intimidade, com a concordância inicial de Norma. Por uma fatalidade do destino, no início do ato sexual, Norma ouve a mesma música, vinda da casa onde se realizava a festa, que ela cantava, quando sua mãe se matou (ela se levantou, pela primeira vez, para ver a filha cantar, viu a sua imagem monstruosa e, horrorizada,

38 FERRAZ JR. Tercio Sampaio. Estudos de filosofia do direito: reflexões sobre o Poder, a justiça, a liberdade e o direito. São Paulo: Editora Atlas, 202. p. 213-229. 
atirou da janela). Por relembrar a culpa traumática que sentiu pela morte da mãe, Norma entra em pânico e passa a repelir Vicente, aos gritos. Ambos estavam sob efeitos de fortes medicamentos psiquiátricos. Ela morde a mão de Vicente, no momento em que este tenta abafar os seus gritos. Em reação à mordida, ele dá um forte tapa nela e a faz desmaiar, saindo com sua moto sem seguida, após ajeitar a roupa da garota. Somente esta saída de moto é vista por Robert.

Percebemos que Vera sente a vingança de Robert como um ato extremamente abusivo e injusto, já que, na sua versão dos fatos, não houve tentativa de violação sexual forçada, mas foi coagida a se tornar um transexual. Neste momento, toda simbologia que aparece no início do filme, no cárcere privado, passa a fazer sentido. Percebemos que a tentativa de suicídio ou de estragar a sua pele, cortando-a, a prática da ioga, as esculturas de Louise Bourgeois, que discutem a ausência de identidade, a escrita na parede, o ato de rasgar os vestidos, e a dor vaginal permanente são referências explícitas do seu sentimento de injustiça opressiva. Significam a preservação de seu desejo de libertação e da negação de sua identidade feminina artificialmente construída.

No final, quando o filme retorna para o ano de 2012, Vera simula uma relação afetiva com Robert, que parece se esquecer de Vicente, como ser que ele odeia ao se apaixonar por sua Gal recriada, através de uma falsa promessa de lealdade. Ele acredita que ela pode ficar "livre", porque está sobre o controle de seu amor, de forma irracional, neste caso em virtude do amor e não mais do ódio que sentia por Vicente. O homo demens domina o homo sapiens, ele não percebe mais que, na esteira do que foi dito por Bauman, seus atos supostamente morais implicam na afirmação de uma mudança de sexo injusta e absolutamente não moral, do ponto de vista de Vera/Vicente. No entanto, vemos ela beijar com carinho a antiga foto masculina de Vicente, num jornal, onde figura como desaparecido. Sabemos, também, que a sua mãe nunca acreditou que ele tivesse morrido, apesar da visão conformada da polícia.

Antes de ir embora, Vera mata Robert e Marília, com um tiro certeiro no coração, um pouco antes da consumação física de seu amor. Seu lado irracional homo demens, ligado ao ódio e ao desejo de vingança, aparece com força. Os papéis se invertem, ela assume também um modelo vertical de justiça contra aquele que foi seu agressor abusivo. Lembramos da reflexões de Elias Canetti, no livro Massa e Poder, em torno do tema da opressão, onde ele explica que o dominado só consegue se libertar psicologicamente desta condição, caso consiga inverter as posições no futuro. ${ }^{39}$ Retorna a sua casa, e reencontra a sua mãe, e fica constrangida ao confirmar que não é reconhecida por ambas, que o corpo de Vicente não existe mais.Reafirma de forma emocionada a sua identidade de gênero masculina, em total desacordo trágico com a sua aparência física feminina. Ela diz para a mãe "eu sou Vicente".

39 CANETTI, Elias. Massa e poder. Brasília: Editora Universidade de Brasília, 1983. p. 209. 
Considerações finais

Pelo exposto em nosso artigo, pudemos demonstrar como a apreensão pósmoderna da relação entre direito e moral, proposta por Bauman, torna-se rica, quando associada ao estudo interdisciplinar relacionado ao filme $A$ pele que habito. Os conceitosimagem da película são exemplares para expor o sentido irracional, aporético e ambivalente da moralidade, não reduzível a esquematizações normativas racionalistas, do tipo moral/ imoral, lícito/ilícito. Ousamos afirmar que a reflexão pós-moderna proposta por Bauman se torna mais clara quando exposta nesta abordagem logopática. A nossa sensibilidade afetiva despertada pela percepção dos conceitos-imagem pode nos ajudar a entender melhor a nossa irracionalidade natural, a nossa zona cinzenta, em termos profundos e existenciais.

Toda a complexa narrativa da trama nos leva à experiência de controversas emoções primárias, no sentido proposto por Hugo Munsterberg, que nos permitem adentrar na consciência subjetiva dos personagens, ver ângulos que eles mesmos não podem enxergar. Vivenciamos o ato de vingança de Robert, que é um homem torturado pelo trágico suicídio de sua esposa e filha. Acompanhamos o seu senso de justiça irracional, que está ao lado do racional e competente cirurgião plástico, que não hesita em tirar proveito pessoal e público, como cientista, destes atos violentos informais e privados. Sentimos os efeitos devastadores que a afirmação concreta de seu senso de justiça provoca em Vera, na mudança de sexo forçada e na implantação da pele artificial Gal. Sentimos sua angústia na sua prisão, sua revolta, o seu desejo de liberdade e de afirmação de sua identidade masculina, num corpo tragicamente transformado em feminino. Ao mesmo tempo, nos compadecemos com a incapacidade moral e psicológica de Robert em perceber que a relação amorosa com Vera seria impossível, devido ao choque intransponível de ações morais e jurídicas. Por ser incapaz de perceber o quanto seus atos, considerados justos e tecnicamente perfeitos do seu ponto de vista, foram abusivos para a destruição da identidade sexual e existencial de Vera, ele acaba sendo dominado por sua criatura, decide abandonar a sua posição de criador e paga com sua vida por esta escolha.

Mas vemos, também, as chamadas emoções secundárias no filme, que brotam da visão logopática da película como um todo. A intenção pós-moderna de Almodóvar, no tratamento do tema, supera a visão tradicional, que levaria o espectador a julgar os personagens e tomar partido em termos morais e jurídicos, a partir da afirmação de códigos éticos absolutos. Ele não pretende que cheguemos à conclusão de que Robert seria um assassino imoral em contraposição à figura de inocente e pura de sua vítima Vicente/ Vera. Ao final, ocorre uma explícita e complexa inversão de papéis, os atos abusivos de Robert, despertam o lado sombrio e irracional de Vicente/Vera, que concretiza o seu plano de vingança e libertação. Quanto mais formamos o quebra-cabeça narrativo, mas a complexidade ético-jurídica dos personagens se amplia, por jogá-los numa crescente e 
incerta zona cinzenta de intenções, gestos e atitudes. Mais difícil se torna julgá-los. Vemos em Almodóvar uma intenção de compreensão pós-moderna desta zona cinzenta de ações e intenções em termos morais e não da afirmação de sua repressão racional.

São Paulo, setembro de 2012.

\section{Referências}

ALMODÓVAR, Pedro. A Pele que habito/La piel que habito. Blu-Ray disco. LK TEL DISTRIBUIDORA DE FILMES LTDA, 2012.

BAUMAN, Zygmunt. Ética pós-moderna. São Paulo: Paulus, 1997.

CABRERA, Julio. O cinema pensa: uma introdução à filosofia através dos filmes. Rio de Janeiro: Rocco, 2006.

CANETTI, Elias. Massa e poder. Brasília: Editora Universidade de Brasília,

FERRAZ JR. Tercio Sampaio. Estudos de Filosofia do Direito: reflexões sobre o poder, a justiça, a liberdade e o direito. São Paulo: Editora Atlas, 2002.

FERRAZ JR, Tercio Sampaio. Introdução ao estudo do direito: técnica, decisão, dominação. 4. ed. São Paulo: Atlas, 2003.

FRANJU, Georges. Olhos sem rosto/ Les yeaux sans visage. DVD disco. Marcus Opus, 2012.

JAPIASSU, Hilton. Interdisciplinaridade e patologia do saber. Rio de Janeiro: Imago Editora, 1976.

KELSEN, Hans. Teoria pura do direito. São Paulo: Martins Fontes, 1987.

MORIN, Edgar. A cabeça bem feita, repensar a reforma, repensar o pensamento. Rio de Janeiro: Bertrand Brasil, 2000.

XAVIER, Ismail. A Experiência do cinema: antologia. Rio de Janeiro: Edições Graal: Embrafilmes, 2008.

. O discurso cinematográfico: a opacidade e a transparência. São Paulo: Paz e Terra, 2005. 